EASTERN EUROPEAN JOURNAL OF TRANSNATIONAL RELATIONS

2017 Vol. 1 No. 1

DOI: 10.15290/eejtr.2017.01.01.04

Szymon Jankiewicz ${ }^{1}$

National Research University

Higher School of Economics in Moscow

Nadezhda Knyaginina ${ }^{2}$

National Research University

Higher School of Economics in Moscow

\title{
The Legal Regulation of Instruments for Identifying and Supporting Gifted and Talented Pupils and Students in Germany ${ }^{3}$
}

\begin{abstract}
This paper describes Germany's policy and regulation of in the sphere of identifying and supporting gifted and talented schoolchildren and students. Particular attention is paid to the programmes of financial support for them, especially children and students from families living under difficult financial circumstances. The identification and support of such children and young people is analysed separately with respect to pupils schoolchildren) and students. The paper outlines the various German laws, foundations (scholarships) and other means aimed at supporting the gifted and talented. The German experience is estimated as successful and can be borrowed by other countries that currently are without such policy and regulation.
\end{abstract}

1 Dr., the Head of the Center for Education Law of the Institute of Education at the National Research University Higher School of Economics (Russia, Moscow). He specializes in public law, legal regulation of education in Russia and abroad, financing of the education system, problems of inequality in education, and balance between accountability, autonomy and rights of the participants of education relations. E-mail: syankevich@hse.ru.

2 Junior research fellow of the Center for Education Law of the Institute of Education at the National Research University Higher School of Economics (Russia, Moscow). Her main research topics are inequality in education, access to education, accountability in education. E-mail: nknyaginina@hse.ru.

3 The article was prepared within the framework of the Academic Fund Program of the National Research University Higher School of Economics (HSE) in 2016-2017 (grant No 16-01-0024) and supported within the framework of a subsidy granted to the HSE by the Government of the Russian Federation for the implementation of the Global Competitiveness Program. 
Keywords: gifted and talented children and students; Germany; identifying; supporting; financing; extracurricular education

\section{Introduction}

Regulating the support of gifted and talented children and students has become more and more important over the last decade or so and Germany is among the most advanced states addressing this issue. One of the reasons for such extensive regulation in Germany is the shortage of skilled professionals. German experience in identifying, financing and otherwise supporting the gifted and talented may serve as a good example for other states.

As a Federal Republic Germany is divided into states that have their own local regulation. The school system is part of the state authority and therefore is highly diverse across the country. According to Art. 30 and 70 sect. 1, of the German Constitution, responsibility for education lies with the 16 federal states of Germany. Therefore, the support for the gifted and talented needs to be analyzed on a state-bystate basis. However, legal regulation is often missing, and gifted and talented pupils and students receive scholarships provided by private foundations. The following essay will give a closer look on the legal regulation of instruments for identifying and supporting gifted and talented children in Germany both at school and university levels.

For the above purpose this essay is constructed in the following way: firstly, it describes the identification and support of gifted pupils (schoolchildren), secondly, it outlines the identification and support of gifted students.

\section{Identification of gifted pupils}

Gifted pupils may be difficult to identify, because they may exhibit different behavioural patterns. For example, if the pupil is bored this may result in bad behaviour and low grades. On the other hand the pupil may appear 'nerdish' to the class by always being the first to answer questions and answering them correctly, and undertaking self-study during breaks. Some might strive to gain the attention of teachers and the class by conspicuous conduct. In other cases the pupil can neither appreciate or identify with the activities of fellow pupils (see "Deutsche Gesellschaft für das hochbegabte Kind," n.d.). Invariably, gifted pupils are constantly searching for higher levels of challenge and normal school workloads and leisure activities are insufficient in meeting their needs. There is also an indicator on the emotional level. Some pupils age beyond their years intellectually, but seem not to be so 
old emotionally. Gifted pupils are often very strict about themselves and their environment, especially towards peers.

Given various indicators and behavioural patterns, a test is one of the first steps to prove intellectual giftedness or a particular talent, but it alone should not be used as a final indicator ("Deutsche Gesellschaft für das hochbegabte Kind," n.d.). If the pupil has an intelligence quotient of more than 130 he or she is seen as a gifted. With an intelligence quotient from 115 to 130 the pupil's talent is regarded as being above average. The test is used to objectify subjective procedures and consequently is not completely precise but it is rather unlikely that the intelligence test is higher than the actual level of intellectual giftedness. However, the test will produce results not the only means available to prove intellectual giftedness. Psychologists take into consideration personal conversations with the pupil and the pupil's parents as well as the child's behaviour.

\section{Support of gifted pupils}

There are many ways and many tools available with which to support gifted pupils in school, or even earlier. Most of the tools are not financially orientated but social and help those pupils to fulfil the workload they need to achieve. Classes for gifted pupils are differently structured than other classes (see "Special classes for talented pupils in schools in Bayern," n.d.). The normal workload is accomplished faster and topics are discussed more profoundly. There is also space for individual creativity and interests and the pupils work with greater independence and autonomy. Sometimes the school itself has special spheres of interest they support, for example, music, sports, maths or the sciences. In some federal states it is possible to take an A-level in sports, which is especially useful for would-be professional athletes who are of school age (see "Standards of Network Support of Talented People NRW," n.d.).

Some German states introduced special classes for gifted pupils in some schools so that those children receive an education that is more fitting for them (see "Special classes for talented pupils in schools in Bayern," n.d.). It is not mandatory to have excellent grades to obtain entry to such classes. Sometimes outstanding creativity or high intelligence quotients are sufficiently decisive to allow them entry. This leads to the fact that pupils attending special classes have access to a higher level of learning than their less intellectually capable peers. Consequently, the social problems the pupils sometimes experience in normal classes are solved by the fact that they are among like-minded classmates. Nevertheless, those classes are rarely introduced. For example, at the moment there are only eight such classes for the whole of Bavaria, which means that pupils who want to attend them often need to travel long distances 
thus divorcing themselves from friends and neighbours who live close by and attend the local school.

Parents need to apply for supporting classes in advance and with the help of the child's current school. The application includes a short supporting explanation, the certificate provided after the third grade, the penultimate certificate of elementary school and additional information relating to special aptitudes. It is a long road to admission. Submission of the application, special tests conducted by the school and a rehearsal session are all taken into consideration.

Many schools do not have special classes but nevertheless they support talented pupils in other ways. Large German support projects are "Jugend musiziert" ("young musicians") a music competition for chidren and adolescents, and "Jugend forscht" ("young researchers") a science competition. Jugend musiziert supports young people that are not mandatorily bound by the school. Free application is open to anyone not older than 20. Schools with a focus on music can apply on behalf of their pupils and support them with special rehearsals or participation in a school-orchestra ("Gymnasium for talented pupils Bischöflichen Marienschule Mönchengladbach," n.d.). Teachers can selectively get in touch with pupils who are suitable for this competition. It is quite common for German schools to work on projects such as this collectively and prepare for the competition during normal lessons so long as the projects fits within the study plan of the state. Teachers help their pupils after classes and sometimes escort them to the competition itself. School assistance aside, would be contestants may themselves apply for entry to "Jugend musiziert".

The aim of the "Jugend forscht" project is to support young people interested in the sciences and to provide them with the opportunity to start working on their preferred discipline as early as possible (see "Project 'Jugend forscht," n.d.). "Jugend forscht" deals with different sciences and supports two age groups: one group is from fourth grade to 14 years of age, and the other is from 15 to 21 years of age.

Many schools appreciate their pupils' work and honour their projects and results afterwards ("Gymnasium for talented pupils Bischöflichen Marienschule Mönchengladbach," n.d.). Nevertheless, one should take into consideration that this is not a normal practice for every school and that the parents of gifted children should themselves research all available support options before making a decision on which school to choose.

One particular programme provided a welcome lift to schools in North RhineWestfalia (NRW). This was the "Netzwerk Hochbegabtenförderung NRW" ["Network Support of talented people NRW"] that started in 2010 and ran until October 2015. The purpose of the programme was to connect many schools in NRW - regardless of form - to improve their ability to work with gifted pupils (see "Netzwerk Hochbegabtenförderung NRW," 2017). The aim was to generate a flow of information between different schools in NRW to improve educational 
facilities for these children. To achieve this end the schools and their teachers were provided with professional advice by the federal government. During conferences, participants developed exercises and concepts tailored to support gifted pupils. Over time the connection between schools grew stronger, making it easier for new schools to enter the programme.

One of the biggest educational foundations in Germany is the "Karg Foundation." The Karg Foundation supports different programmes but also organises programmes of its own (see "Foundation for Gifted Kids 'Karg Stiftung'," n.d.). The foundation was established in 1989 with the aim of improving support to gifted children within the school system. The primary objective of the foundation is not to overextend education or grow geniuses but rather to improve the personal development of pupils deemed to be gifted and promote their potential ("Foundation for Gifted Kids 'Karg Stiftung'," n.d.). The Karg Foundation is one of the main supporters of the "Netzwerk Hochbegabtenförderung NRW" and this project fits perfectly into the framework of its objectives. It connects different institutions to improve the overall support structure for gifted children.

The Karg Foundation places special emphasis on supporting gifted pupils at school ("Foundation for Gifted Kids 'Karg Stiftung," n.d.). Exceptional talents need to be integrated into normal school life and it is obvious that different levels of learning will exist in a class of up to 30 children. But these differences can only be normal up to a certain point. Beyond that point the differences can no longer be compensated for without overextending the normal group of pupils and underchallenging those who are gifted. Therefore, special programmes need to be introduced for gifted pupils to create homogeneous learning groups. This is where the Karg Foundation comes in and it reaches this aim with financial as well as practical support. Collectively state governments, the federal government and the Karg Foundation, support many other projects of this nature.

The Karg Foundation itself is divided into two sub-foundations: "Karg Innovation" and "Karg Transfer". The first deals with development of the educational system for gifted and talented pupils and the quality of education it provides, including facilities for studies and research. The second focuses on the impact and practical aspects of support on the pupils' education level.

The starting point of support is the further education of teachers and other educators because only with teachers trained to an advanced degree of proficiency, can the gifted and talented be provided with a level of support suited to their needs ("Foundation for Gifted Kids 'Karg Stiftung,", n.d.). To acknowledge the best projects for improving the support of gifted children, the "Karg Award" was introduced in 2009 and is awarded every second year ("Foundation for Gifted Kids 'Karg Stiftung,," n.d.). The winner receives a donation of $€ 50.000$ toward the further improvement of a particular project. The support of gifted and talented pupils is a mandatory inclusion because having a higher intelligence quotient than other 
children ceases to be an advantage in the absence of the facilities and people to cope with it. Most of the time the pupils themselves are unaware of their particular gifts or talents and therefore organisations and projects capable of recognizing their existence and working with the pupils concerned to develop them, is of paramount importance. It can rightly be said that the support of gifted children is just as important as the support of children who have a learning disability. Unfortunately, in German society, supporting the latter appears to attract more attention than supporting the former.

Besides ordinary schools, which provide special classes or courses, there are also specialised boarding schools for the gifted and talented. Typically they are privately run organisations and therefore very expensive. However, pupils attending these boarding schools are assured of an educational experience specifically structured to support and promote their talents to optimal effect (see "Sankt Afra, Meissen Sächsisches Landesgymnasium für Hochbegabte," n.d.). One such example is the secondary school "Sankt Afra" in Sachsony. Here the pupils live together, each sharing a room with two others, and studies are adjusted to meet the pupils needs. The daily workload is much higher than in ordinary schools ("Sankt Afra, Meissen - Sächsisches Landesgymnasium für Hochbegabte," n.d.). The pupils learn three foreign languages - two is normal in other secondary schools - and likewise they have three extension courses whereas the pupils of ordinary schools only have two. Competitions are also part of the study programme and one main point of the concept is learning from each other. In this respect age groups are sometimes mixed enabling beginners to learn from their more experienced classmates. The schools have mentors who teach the pupils throughout the day but not in the sense of traditional teachers, rather they supplement teaching with a bespoke educational experience by providing input on an individual basis as and when required.

Financial support provided direct to the pupils, or to their parents, is not common in Germany. Special programmes provided at school or by way of extra-curricular study, are mostly the only means of support available. The aim is more to promote the talents of pupils by offering special activities to further their mental and emotional skills, not to reward them financially because of their intelligence quotient.

Nevertheless, there are scholarships available that do financially support gifted pupils. The "Dornier Foundation" provides around 12 new scholarships a year for suitable pupils who wish to attend a boarding school ("Sankt Afra, Meissen Sächsisches Landesgymnasium für Hochbegabte," n.d.). The actual amount of financial support depends on the income and financial circumstances of the parents. A scholarship runs until completion of the A-level or the International Baccalaureate. One of only five schools can be attended with the Dornier Foundation scholarship (see "Foundation for talented students 'Dornier Stiftung'," n.d.). Therefore, to qualify for the scholarship, applicants first need to demonstrate willingness to live in a location that may be far away from their home. Other qualifying factors requiring to be demonstrated are: that without the scholarship the applicant would 
have no possibility of obtaining a fitting standard of education due to the financial circumstances of his/her parents; that besides the normal requirement of good grades and special interest in one particular topic, the applicant has the ability to work in a team ("Foundation for talented students 'Dornier Stiftung'," n.d.); that in all other respects the applicant fulfils the requirements of the particular school.

Another possibility to obtain a scholarship is via the "Stiftung für sozial schwache, hochbegabte Kinder und Jugendliche" which is a foundation supporting children lacking the family background that might otherwise allow them to benefit from an education suited to their particular talent(s) (See "Stiftung für sozial schwache, hochbegabte Kinder und Jugendliche," n.d.). Here the foundation not only supports pupils of school age but also students. As befor the monetary value of the scholarship depends on the financial situation of the family. Sometimes it constitutes a one-time payment to a pupil or student, in other cases it leads to a full scholarship.

One special supporting programme is "MINT-EC" (see "National Centre of Excellence 'Mintec'," n.d.). This is a special organization for people with talents in the field of mathematics, computer sciences, natural sciences and technology. The aim of the foundation is not only to support children but also to build up a network that helps teachers and parents to work with gifted children. Any school, which places special emphasis on one of the aforementioned topics, can apply for inclusion in the programme. The pupils themselves benefit from events which deal with topics in a particular area (see "National Centre of Excellence 'Mintec," n.d.). The aim of the organisation is to ensure education in the fields of mathematics, science and technology to mitigate a shortage of skilled professionals in these disciplines in Germany (see "National Centre of Excellence 'Mintec,"” n.d.). Especially in relation to the aforementioned subjects, universities have special interests in supporting school education. The RWTH Aachen, for example has a special focus on technical subjects and is therefore interested to enrol school-leavers who already have some knowledge in that particular field. RWTH Aachen therefore supports talented children at school and offers some schools the opportunity to extend their scientific and technical branch in cooperation with "MINT-EC" (see "National Centre of Excellence 'Mintec'," n.d.).

\section{Identification of gifted students}

The identification of gifted students can occur at various stages of education and may depend on family background and behaviour of the child at school. It may include an exceptionally high-level of performance, either in a particular field or across a range of endeavours, as well as an unrecognized potential for excellence (Freeman, 2002, p. 1). Sometimes it may be identified using more or less measurable aspects, such as high marks in university, IQ-level or overall GPA, capabilities in 
arts and sports, and, in terms of psychological constructs, a student's overall level of intelligence and creativity (Freeman, 2002, p. 1). On the other hand, a single characteristic can indicate a special gift or talent in an otherwise unexceptional pupil (Freeman, 2002, p. 3).

Below is a general outline of German regulation relating to the support of gifted students as well as of various incentives that are used for this purpose, namely: release from university fees; foundations; German scholarships; immaterial (ideal) promotion; and promotion for semesters abroad.

\section{BAföG (German Federal Law on Training and Education Promotion)}

Consistent with the provisions of Art. 26 of the Universal Declaration of Human Rights, in Germany everyone has the right to education. This right is implemented in the form of compulsory education. The statutory period for compulsory education depends on the federal state, and ranges from nine-years to twelve-years ${ }^{4}$. To support the right to further education, independent of the financial situation of parents, in 1971 the German government introduced the Bundesausbildungsförderungsgesetz or Federal Training Assistance Act (abbreviated BAföG), which regulates the availability of federal student grants and loans for secondary schools and universities (Bundesausbildungsförderungsgesetz, 1971).

According to para. 1 BAföG, every young adult over school leaving age has the right of access to vocational training or higher education even if they lack the financial resources to support themselves. The assistance provided by the act is not specifically based on talent or scholastic achievement. However, it is the most common way of support for university students in Germany. One can receive the promotion for training and education for any secondary schools, trade schools, colleges, universities of applied sciences and universities (Bundesausbildungsförderungsgesetz, 1971, para. 2 sect. 1). BAföG supports students with a complete scholarship, funded by way of a $50 \%$ federal grant and a $50 \%$ interest free federal loan.

The assistance scheme is open to students with German citizenship, citizens of a European Union member state, or citizens of other contract states within the European Economic Area. It is also open to foreign nationals that have their usual place of residence in Germany and who qualify as refugees under the Convention Relating to the Status of Refugees and Homeless Foreigners, in accordance with the Federal Law on the legal status of homeless foreigners in federal territory ${ }^{5}$ (Bundesausbildungsförderungsgesetz, 1971, para. 8 sect. 1). Assistance can only be

4 For example 10 years in Northrhine-Westphalia, para. 37, 38 SchulG NRW, 9 years in Hessen, para. 39 SchulG G-V, and 12 years in Bremen, para. 54 Brem. SchulG.

5 There is no official translation of the name of the act in English. The official German name is "Gesetz über die Rechtsstellung heimatloser Ausländer im Bundesgebiet". 
provided if the course of study is started before the age of 30 (secondary school training or batchelors degree courses), or before the age of 35 in respect a master's degree course (Bundesausbildungsförderungsgesetz, 1971, para. 10). The duration of assistance depends on the number of semesters needed to complete a course (Bundesausbildungsförderungsgesetz, 1971, para., sect. 2). For example, a typical bachelor's degree course in Germany lasts for six semesters (three years) and therefore the assistance provided is limited to cover that number of semesters. Such period can be extended but only under very specific circumstances i.e. if the students studies were interrupted by a prolonged period of illness or such similar circumstance (Bundesausbildungsförderungsgesetz, 1971, para. 15, sect. 3).

The actual monetary value of the assistance provided depends on the financial resources of the student and/or student's parents, which is means-tested. Typically the monthly allowance to cover attendance at higher professional schools, academies and universities is $€ 373$ This is supplemented by an accommodation allowance of €49 per month (if the student lives with his/her parents ) or €224 per month (if living away from home in rented accommodation), para. 13 BAföG. The maximum allowance that can be granted as a university student is $€ 670$ per month which includes an addition for insurance.

However, the interest-free loan element of BAföG assistance, needs to be repaid to the state in installments with payment commencing $4 \frac{1}{2}$ years after the end of the promotion. The amount to be repaid has an upper limit of $€ 10.000$ payable over a maximum term period of 20 years. Any amount that remains outstanding at the end of the term period still requires to be paid but is then subject to $6 \%$ interest on the outstanding balance (Bundesausbildungsförderungsgesetz, 1971). Calculation of the amount that can be made available under the promotion is dependent on the income of both parents and the student's own estate.

\section{Release from university fees}

Since the autumn semester 2014-2015 all federal states throughout Germany abolished fees for university. This is another step to ensure everybody's right for education according to Art. 26 of the Universal Declaration on Human Rights. Germany is also a signatory to the International Covenant on Economic, Social and Cultural Rights. The Covenant states in art. 13 sect. 2 c) that "higher education shall be made accessible to all, on the basis of capacity, by every appropriate means, and in particular by the progressive introduction of free education."

Introducing or abolishing university fees has been the subject of prolonged political debate for many, many years. However, during the last decade seven federal states, while introducing university fees, also offered the possibility of release from them. The most common reason for release was the case of hardship. Again, this 
release was conditional based on the social and financial situation of the student or the student's family.

Nonertheless, a release for gifted students was possible as well. Again this differed from state to state. For example, in Baden-Württemberg a release was possible for students, who possessed a far above-average talent or, who during their studies, performed outstandingly (para 6 sect. 1 sentence 3 HSchulGebG BW 6 , which is no longer enacted $)^{7}$.

In order to identify gifted students usually their GPA is used and the best 5 to $10 \%$ are regarded as talented. This was, for example, the case in Bavaria according to para. 71 sect. 5 sentence 3 BayHSG$^{8}$. This had been criticized arguing that gifted or talented students can follow their path without release from university fees since they can finish their studies faster as well as having more time available for part-time work. The underlying factor, was that people were afraid that many students with wealthy parents would gain a financial advantage that was not needed. As mentioned above, university fees have been abolished and therefore this is no longer a political topic. Now only a contribution needs to be paid and even that is subject to release under special circumstances, as for example hardship cases.

\section{Foundations (scholarships)}

The most common way in Germany to support gifted students is by way of scholarships. This, as mentioned above, often happens through private foundations and legal regulation is not necessarily needed. According to para. $80 \mathrm{BGB}^{9}$ for the formation of a lawful foundation an endowment transaction ${ }^{10}$ and the recognition of a responsible authority is all that is needed. Which authority is responsible depends on the particular Foundation Law of the particular state. Furthermore, foundations have to have a certain estate. For example, according to para. 3 sect. 2 of the Foundation Law of the Saarland, the estate of a foundation needs to be sufficient to meet the

6 Full name of the law is "Hochschulgebührengesetz Baden-Württemberg", which can be translated as "University Fees Law of Baden-Württemberg".

7 In the case of VG Freiburg (Breisgrau), the decision of November 14th, 2007 - 1 K 1146/07 amplifies the interpretation of that legislation. However, university fees have been abolished in 2012 in Baden-Württemberg and therefore the legislation has been made void.

8 The full name of this law is "Bayrisches Hochschulgesetz", which can be translated as "Bavarian University Law".

9 BGB stands for Bürgerliches Gesetzbuch and is the German Civil Law Code.

10 "A lifetime endowment transaction must be in writing. It must contain the binding declaration by the founder that he will dedicate assets, which may also be intended for depletion, to achieve an object specified by himself. The endowment transaction must give the foundation a charter with provisions on 1. the name of the foundation, 2. the seat of the foundation, 3. the objects of the foundation, 4. the assets of the foundation, 5. the composition of the foundation board.", para. 81 BGB. 
objectives of the foundation and requires to be funded from the earnings of the estate of the foundation. While there is no lower monetary limit on the value of the estate, in practice a contribution of $€ 50,000$ is common practice and the authorities will normally accept it.

Firstly, some of the foundations are established by the Federal Republic of Germany. One such is the Studienstiftung des Deutschen Volkes (the German Academic Scholarship Foundation) ${ }^{11}$, which promotes gifted students in the name of the Federal Republic of Germany. According to its statutes, it supports "the university education of young people who, on account of their exceptional academic or artistic talents and of their personality, are expected to achieve outstanding results and make a special contribution to society as a whole" ("The statute of the German Academic Scholarship Foundation," n.d.). The German Academic Scholarship Foundation is primarily funded by the Federal Ministry of Education and Research. The support of the German Academic Scholarship Foundation is either financial or ideal promotion. Ideal promotion includes different academies, conferences or language courses (“German Academic Scholarship Foundation," n.d.). A student can receive the scholarship by either being recommended for it by the university or by self-application.

Secondly, there are also scholarships established by religious institutions. One of those is the Cusanuswerk which was founded in 1956 (see "Student's Scholarchips," n.d.). The foundation supports students during their studies and their promotion but only after being recommended by school directors, professors or employees of the pastor of the university. However, self-application is also possible. The Cusanuswerk expects the student to perform excellently in university, be curious and be prepared to take responsibility as well as to take their own faith seriously and live with the church ("Catholic Foundation for talented students 'Cusanuswerk," n.d.). Another foundation, the Hanns-Seidel-Foundation, is closely connected to the Christ-Social Union that is only active in Bavaria. Here, a scholarship is awarded through selfapplication ("Christlich-Soziale Union in Bayern," n.d.). There is also the Protestant Studienwerk Villigst which, as the name implies, supports members of the protestant church. The foundation was founded in 1948 as a result of the failure of the academic layers during Nazism ("Protestant Academic Foundation of Germany," n.d.). Another religiously motivated foundation is the Ernst Ludwig Ehrlich Studienwerk which primarily addresses Jewish students and Jewish doctoral students in order to support talents of the Jewish community. Expected are above average performances during studies, but also further engagement in Jewish communities or social areas ("Jewish community for Talented People 'Ernst Ludwig Ehrlich,'” n.d.).

Thirdly, there are also political foundations established in Germany. The Friedrich-Ebert-Stiftung is the country's oldest political foundation. The main

\footnotetext{
11 Translated as "German Academic Scholarship Foundation".
} 
condition is a talent which can be identified through above average scholastic or study-related performances, character image and political and/or social engagement ("Friedrich Ebert Fiundation - Scholarships for Talented Students," n.d.). To obtain promotion students can themselves apply direct to the Friedrich Ebert Stifung, they do not have to be recommended. Different parties support different political foundations. For example, the Friedrich-Naumann-Stiftung für die Freiheit (for freedom) is close to the FDP, which is the German Liberal Party. Conditions for a scholarship are talent, characteristics and liberal political and social involvement ("Friedrich Naumann Foundation for Freedom is the foundation for liberal politics in the Federal Republic of Germany," n.d.). Other foundations are the Heinrich-BöllFoundation supported by Alliance 90/The Greens, the Konrad-Adenauer-Foundation supported by the Christian Democratic Union, the Rosa-Luxemburg-Foundation supported by the left-wing party as well as the Foundation of the German Economy which supports students with entrepreneurial spirit. Finally, some of the foundations are established by trade unions. For example, one of the biggest foundation promoting talented students it the Hans-Böckler-Stiftung of the German Trade Union Association. 1750 scholars were promoted, who otherwise would not have been able to finance their studies. The German Trade Union Association can recommend students as long as they are active in the union. A student who is not a member of the union, but otherwise matches the criteria, can self-apply ("Hans Böckler Foundation," n.d.).

\section{Deutschlandstipendium (Germany Scholarship)}

The Deutschlandstipendium is comparatively new as opposed to other scholarships, but is one of the few that is actually funded by the Federal Republic of Germany. Since 2011 the Deutschlandstipendium ${ }^{12}$ has been targeting gifted students of all nationalities of all states and officially recognized universities throughout Germany. The Deutschlandstipendium was introduced with the "Law for the Establishment of a National Scholarship Programme" (Gesetz zur Schaffung eines nationalen Stipendienprogramms, n.d.). According to this programme, the scholarship is used to finance $50 \%$ of the costs: one half of the scholarship is funded by the Federation and the other half is funded privately. The Deutschlandstipendium has the following selection criteria: social engagement, willingness to show responsibility, family circumstances and personal circumstances (para. 3 sentence 2 StipG). These criteria have to be considered equally with talent and performance.

The scholarship may only be announced by a university and the "Deutschlandstipendium" has to be announced at least once a year. The upper 
limit of promotion according to para. 11 section $4 \mathrm{StipG}$, is determined by the Federal Ministry of Education and Research in accordance with para. 4 section 2 StipV. Calculation is based on the number of students attending university in the Federation ("Häufig gestellte Fragen zum „Stipendienprogramm-Gesetz (StipG)“ und zur Stipendienprogramm-Verordnung (StipV)," n.d.). Each university receives a certain quota of scholarships it can award, however, they must find the private means to supplement the scholarship themselves. This is one of the reasons why the Deutschlandstipendium is still facing difficulties and thus far has not fulfilled the hopes that the scholarship promised. In 2011 the Deutschlandstipendium only promoted $0.2 \%$ of all 2.4 million students in Germany. During the first year of the scholarship, some seven-million Euros of the money allocated remained unused and therefore neither supported students or other educational projects.

The success of the Deutschlandstipendium is widely disparate throughout the federal states of Germany: economically strong states find it easy to find private sources of funding to supplement the program, whereas weaker states find it impossible. One example is Hamburg, in which only 16 of 328 possible scholarships were awarded. However, the universities in Mannheim in Baden-Württemberg had more offers of private financial support for the Deutschlandstipendium than scholarships they were able to award. Following this they developed the "Mannheimer Scholarships" which supports students with monthly allowance of $€ 150$ (Maisch, 2012).

\section{Immaterial (Ideal) promotion}

Another way of being promoted as a gifted student is by way of immaterial (ideal) promotion. Immaterial promotion means that the student is not supported financially but through other means.

Here the promotion is not only open to extremely smart students for academic achievement, it is also available to especially successful and talented athletes. In general, the application for high performance athletes is made under the same conditions as other applications from the field of academic study at universities. However, by being a member of a federal level founded squad in one of the central associations that form the German Olympic Sports Confederation (DOB), allows an athlete to file a special application for admission to university. If the admission is restricted nationwide, the application needs to be directed to the Foundation for University Admission in Germany, which is based on the State Treaty on University Admission and to which all 16 federal states are signatory (Staatsvertrag über die Errichtung, 2008). If the admission is locally restricted, the application needs to be filed to the university ("Merkblatt: Zulassung von Spitzensportlern und Spitzensportlerinnen," 2015). 
Article 9 of the State Treaty makes provision for quotas on advanced admissions. However, the quota itself varies from federal state to federal state and is regulated by local laws on university admission. In Baden-Württemberg for example, the overall advanced admission quota is $20 \%$ and provides the opportunity for high performance athletes to obtain a place at university ${ }^{13}$. In North Rhine-Westphalia high performance athletes can even be selected ahead of the applicants that fall under the quota of Article 9 and are not counted in the quota (para. 4 sect. 3 of the Law On University Admission of North Rhine-Westphalia). However, in most instances, such early admissions do not apply where the application is for studies in medicine, pharmacy and dentistry.

\section{Online scholarships}

Nowadays, so-called online scholarships are also offered to students. Online scholarships are communities which offer different possibilities. For example, the communities work together with a variety of companies and therefore offer internships, workshops and other events in cooperation with them.

E-fellows.net ("E-fellows.net - scholarships for talented students," n.d.) is one such online scholarship and was founded by Deutsche Telekom AG, McKinsey \& Company and the Holtzbrinck Publishing Group. In fact E-fellows has the distinction of being the first online-based scholarship in Europe. Scholarship holders can benefit from job offers and internships, subscriptions to newspapers and magazines, mentoring, city groups and the online community. The scholarship is given to students with excellent marks in their Abitur (the German A-levels) or outstanding performance during university studies. Some students are presented with the scholarship when their Abitur is handed out by their school, but self-application is also possible.

\section{Promotion for semester abroad}

Through the on-going process of globalization, not only in Europe but worldwide, university students are more often than not expected to spend at least one semester abroad to gain new experiences. Since living expenses and university fees in many countries are more expensive than they are in Germany, many scholarships offer support for this as well.

Again, financial support is possible through BAFöG. For the stay in a foreign country an additional reward is possible under the BAFöG Additional Reward For 
Stays Abroad Decree ${ }^{14}$. The conditions are less strict and increasing number of students receive BAFöG for their stay abroad.

Also the DAAD (German Academic Exchange Service) is very active. It is the world's largest funding organization for the international exchange of students and researchers. "Its budget is derived mainly from the federal funding budgets of various ministries, primarily the German Federal Foreign Office, but also from the European Union and a number of enterprises, organisations and foreign governments" ("German Academic Exchange Service," n.d.). It provides more than 110,000 German and international scholars worldwide with the opportunity to study or work abroad for a limited period of time. The criteria for a scholarship of the DAAD vary depending on the program applied for, but most of the time above-average grades, a good knowledge of languages and social engagement are expected

\section{Conlusion}

Gifted children may be difficult to identify, because they do not necessarily exhibit different behaviour. However, given various indicators and behavioural patterns, a test is one of the first steps to prove intellectual talent but they should not be used as an affirmative indicator.

There are many ways and tools to support gifted children in school or, in some instances, even earlier. Some German states introduced special classes for gifted pupils in some schools to enable those children to receive an education more fitting for them. Many schools do not have special classes but nevertheless they support talent in other ways.

Big German support projects are "Jugend musiziert" ("young musicians") and "Jugend forscht" ("young researchers"). "Jugend musiziert" supports young people that are not mandatorily bound by the school. The aim of the project "Jugend forscht" is to support young people who are interested in science and to give them the opportunity to start working with their preferences as early as possible.

One of the largest foundations in Germany is the "Karg Foundation". The Karg Foundation is divided in two sub-foundations: "Karg Innovation" and "Karg Transfer". The first deals with development of the educational system for gifted pupils and the quality of their education. Studies and research are included. The second, on the other hand, deals with the practical aspects and impact of support on the pupil's education level. There is also a separate "Karg Award" for exceptional teachers in this field.

Besides normal schools, which just have special classes or courses, there are also boarding schools which cater for gifted pupils which are privately organized and

14 Vaguely translated; the German name is "BAFög-Auslandszuschlagsverordnung". 
therefore very expensive. However, financial support provided immediately to gifted pupils or to their parents is not common in Germany. Special programmes at school or during free time are mostly the only support. Nevertheless, there are scholarships supporting gifted pupils financially (e.g., "Dornier Foundation", "Stiftung für sozial schwache, hochbegabte Kinder und Jugendliche", and "MINT-EC").

Identification of gifted students can start at different stages of education and may depend on family background and the behaviour of the child at school. A talent (gift) may include exceptionally high levels of performance, whether across a range of endeavours or in a particular field, as well as an unrecognized potential for excellence.

To support everybody's right to further education independent of the financial circumstances of their parents, the German government introduced the German Federal Law on Training and Education Promotion (abbreviated BAföG) in 1971. It functions on the basis of a 50\% federal grant and a 50\% interest-free federal loan, with the loan element being repaid from the student's future earnings over a term period of twenty-years.

Since the autumn semester 2014-2015, all federal states throughout Germany abolished university fees. The introduction/abolishment of university fees had been a longstanding political debate over a period of many years. Nevertheless, a release from the payment of fees for particularly talented students was always possible.

The most common way in Germany to support individual talent is by way of scholarships. Firstly, some of the foundations are established by the Federal Republic of Germany. Secondly, there are also scholarships established by religious institutions. Thirdly, there are political foundations established in Germany.

Another way of being promoted as a gifted student is the way of immaterial (ideal) promotion. Not only is this available to extremely smart students but also to especially successful and talented athletes. Nowadays, so-called online scholarships are also offered to students. Online scholarships are communities, which offer different possibilities to students. For example, E-fellows.net ("E-fellows.net - scholarships for talented students," n.d.), founded by Deutsche Telekom AG, McKinsey \& Company and the Holtzbrinck Publishing Group, is one of those online providers of scholarships.

Through the on-going globalization process, not only in Europe but worldwide, university students are more often than not expected to spend a semester abroad for the purpose of gaining new experience. In Germany the DAAD, (the German Academic Exchange Service) is very active in this area. It is the world's largest funding organization for the international exchange of students and researchers.

Policy recommendations: Germany has developed a massive variety of measures identifying and supporting gifted children and students. Apart from separate federal law regulating this support, there are many other instruments in place; namely, different foundations providing scholarships, that are backed both by public and 
private institutions, including even online support. Given that Germany and Russia share the same feature of being federal states, Germany's experience in identifying and supporting children with particular gifts, academic or otherwise, might well be viewed as a beneficial development in Russia's own regulation and policy measures relating to education.

\section{REFERENCES}

Bundesausbildungsförderungsgesetz (1971). BGB1. I S. 1409. Retrieved from https://www.bafög.de/ de/bundesausbildungs--foerderungsgesetz---bafoeg-204.php

Catholic Foundation for talented students "Cusanuswerk." (n.d.). Retrieved February 6, 2017, from https://www.cusanuswerk.de/

Christlich-Soziale Union in Bayern. (n.d.). Retrieved February 6, 2017, from http://www.hss.de

Deutsche Gesellschaft für das hochbegabte Kind [German Society for Gifted Kids]. (n.d.). Retrieved February 6, 2017, from http://www.dghk.de/

E-fellows.net - scholarships for talented students. (n.d.). Retrieved February 6, 2017, from http:// www.e-fellows.net/About-us/For-students-and-young-professionals/We-connect-the-best/

Foundation for Gifted Kids "Karg Stiftung.” (n.d.). Retrieved from http://www.karg-stiftung.de/ stiftung/

Foundation for talented students "Dornier Stiftung." (n.d.). Retrieved February 6, 2017, from http:// www.dornierstiftung.de/

Freeman, J. (2002). Out-of-school educational provision for the gifted and talented around the world. Report for the Department for Education and Skills (pp. 1-195). London: UK Government. Retrieved from http://www.joanfreeman.com/pdf/Text_part_one.pdf

Friedrich Ebert Fiundation - Scholarships for Talented Students. (n.d.). Retrieved February 6, 2017, from http://www.fes.de/studienfoerderung

Friedrich Naumann Foundation for Freedom is the foundation for liberal politics in the Federal Republic of Germany. (n.d.). Retrieved February 6, 2017, from https://www.freiheit.org

German Academic Exchange Service. (n.d.). Retrieved February 6, 2017, from https://www.daad.de/ der-daad/ueber-den-daad/portrait/en/29143-the-internationalisation-agency/

German Academic Scholarship Foundation. (n.d.). Retrieved February 6, 2017, from https://www. studienstiftung.de/studienfoerderung/

Gesetz zur Schaffung eines nationalen Stipendienprogramms. Retrieved from http://www.gesetze-iminternet.de/stipg/index.html\#BJNR095700010BJNE000600000

Gymnasium for talented pupils Bischöflichen Marienschule Mönchengladbach. (n.d.). Retrieved February 6, 2017, from http://marienschule.de/

Hans Böckler Foundation. (n.d.). Retrieved February 6, 2017, from http://www.boeckler.de

Häufig gestellte Fragen zum „Stipendienprogramm-Gesetz (StipG)“ und zur StipendienprogrammVerordnung (StipV). (n.d.). Ministry of Education, Science and Culture Thüringen. Retrieved 


\section{EASTERN EUROPEAN JOURNAL OF TRANSNATIONAL RELATIONS}

from https://www.thueringen.de/imperia/md/content/tmbwk/wissenschaft/studium/ deutschlandstipendium/faq_s_zum_stipg_und_zur_stipv.pdf

Jewish community for Talented People "Ernst Ludwig Ehrlich.” (n.d.). Retrieved February 6, 2017, from http://www.eles-studienwerk.de

Maisch, A. (2012, January 18). "Deutschlandstipendien” für die Elite: Wir sind die 0,2 Prozent. Spiegel Online. Retrieved from http://www.spiegel.de/lebenundlernen/uni/deutschlandstipendien-fuerdie-elite-wir-sind-die-0-2-prozent-a-808168.html

Merkblatt: Zulassung von Spitzensportlern und Spitzensportlerinnen. (2015, February). HeinrichHeine-Universität Düsseldorf. Retrieved from http://www.sportstadt-duesseldorf.de/wpcontent/uploads/2015/06/Merkblatt_Zulassung_Spitzensport2015_02.pdf

National Centre of Excellence “Mintec.” (n.d.). Retrieved February 6, 2017, from https://www.mint-ec. de/home.html

Netzwerk Hochbegabtenförderung NRW [Network Support of talented people NRW]. (2017, February 6). Retrieved from http://www.zukunftsschulen-nrw.de/

Project "Jugend forscht" [Young Researchers]. (n.d.). Retrieved February 6, 2017, from http://www. jugend-forscht.de

Protestant Academic Foundation of Germany. (n.d.). Retrieved February 6, 2017, from http://www. evstudienwerk.de

Sankt Afra, Meissen - Sächsisches Landesgymnasium für Hochbegabte. (n.d.). Retrieved February 6, 2017, from https://www.sankt-afra.de/landesgymnasium-sachsen.html

Special classes for talented pupils in schools in Bayern. (n.d.). Retrieved February 6, 2017, from http:// www.km.bayern.de/

Staatsvertrag über die Errichtung einer gemeinsamen Einrichtung für Hochschulzulassung (2008). Retrieved from https://recht.nrw.de/lmi/owa/br_vbl_show_pdf?p_id=12301

Standards of Network Support of Talented People NRW. (n.d.). Retrieved February 6, 2017, from https://www.standardsicherung.schulministerium.nrw.de/cms/

Stiftung für sozial schwache, hochbegabte Kinder und Jugendliche. (n.d.). Retrieved February 6, 2017, from http://www.seli-stift.de/bewerbung.html

Student's Scholarchips. (n.d.). Retrieved February 6, 2017, from http://www.sueddeutsche.de/bildung/ begabtenfoerderungswerke-vergeben-stipendien-geld-gibts-nur-fuer-die-besten-1.1289036

The statute of the German Academic Scholarship Foundation. (n.d.). Retrieved from https://www. studienstiftung.de/satzung/ 